ROCZNIK ADMINISTRACJI PUBLICZNEJ 2020 (6)

ARTYKUtY / ARTICLES

Administracyjne prawo materialne

Administrative material law

AgniesZKa Kania ${ }^{1}$

\title{
Zwrot nieruchomości przeznaczonych pod drogi publiczne w trybie przepisów szczególnych - zarys problemu
}

\section{Wprowadzenie}

Rosnące zapotrzebowanie na infrastrukturę komunikacyjną i dynamiczny postęp techniczny w tej sferze życia społecznego pociąga za sobą ryzyko wadliwych rozstrzygnięć administracyjnych, skutkujących odebraniem praw własnościowych do nieruchomości przeznaczonych pod drogi publiczne, a następnie niewykorzystanych na cel wywłaszczenia. Przejęcie prawa własności do takich nieruchomości stawia pod znakiem zapytania legalność późniejszego dysponowania nieruchomością przez podmiot publicznoprawny jak właściciel. Z woli prawodawcy prawa majątkowe odjęte w ramach tzw. wadliwego użycia ${ }^{2}$ podlegają zwrotowi, co nie budzi wątpliwości na podstawie uregulowań ustawy o gospodarce nieruchomościa$\mathrm{mi}^{3}$. Jednakże, dla inwestycji drogi publicznej, ustawodawca zdecydował się wprowadzić obowiązujące równolegle unormowania lex specialis, które stały się podstawą rozbieżności orzeczniczych i niejasności, co do legalności zwrotu.

Celem niniejszego opracowania pozostaje próba odpowiedzi na pytanie o dopuszczalność zwrotu nieruchomości drogowych w trybie przepisów szczególnych, a mianowicie, czy w obecnym stanie prawnym jest możliwy zwrot nieruchomości niewykorzystanych na cel wywłaszczenia, a przejętych na podstawie decyzji o zezwoleniu na realizację inwestycji drogowej. Co za tym idzie, koniecznym stanie się wskazanie właściwej postawy prawnej w tym zakresie.

1 Mgr. Agnieszka Kania, magister, Uniwersytet Pedagogiczny im. KEN w Krakowie.

2 Wyrok TK z dnia 13 grudnia 2012 r., P 12/11, Legalis nr 549572.

3 Ustawa z dnia 21sierpnia 1997 r. o gospodarce nieruchomościami (tekst jedn. Dz.U. z 2020 r., poz. 65) - dalej jako: u.g.n. 
Dla realizacji przyjętych założeń, w pierwszej kolejności zostanie przedstawiona istota inwestycji drogowych, którą następnie uzupełni charakterystyka obowiązujących uregulowań prawnych dotyczących zwrotu nieruchomości, by przez analizę stanowiska judykatury zweryfikować postawioną hipotezę badawczą.

\section{Inwestycja drogowa jako cel publiczny}

Kwalifikacja inwestycji drogi publicznej jako inwestycji o charakterze celu publicznego jest o tyle istotna, iż zgodnie $\mathrm{z}$ art. 21 ust. 2 Konstytucji RP ${ }^{4}$ możliwość odjęcia lub ograniczenia praw rzeczowych i obligacyjnych do nieruchomości jest możliwa wyłącznie, gdy podmiot publicznoprawny dokonuje jej na cel publiczny i za słusznym odszkodowaniem. Modelowo jedną z przesłanek legalności wywłaszczenia pozostaje więc realizacja inwestycji celu publicznego. Ustawodawca wprowadził definicję legalną inwestycji celu publicznego w ustawie o planowaniu i zagospodarowaniu przestrzennym ${ }^{5}$, którą jednak należy odczytywać w bezpośredniej korelacji $z$ art. 6 u.g.n. Ten ostatni przepis (art. 6 u.g.n.) nie zawiera klasycznej definicji, a tylko enumeratywne wyliczenie inwestycji, którym nadano kategorię celu publicznego (definicja przez wyliczenie) ${ }^{6}$. Tym samym, żadna inna inwestycja służąca społeczności nie może otrzymać statusu celu publicznego poprzez wykładnię rozszerzającą, jeśli nie została wyraźnie wskazana w art. 6 u.g.n. lub w innych przepisach rangi ustawy ${ }^{7}$.

Abstrahując od powyższego, według art. 2 pkt 5 u.p.z.p., inwestycją celu publicznego są ,,działania o znaczeniu lokalnym (gminnym) i ponadlokalnym (powiatowym, wojewódzkim i krajowym), a także krajowym (obejmującym również inwestycje międzynarodowe i ponadregionalne), oraz metropolitalnym (obejmującym obszar metropolitalny) bez względu na status podmiotu podejmującego te działania oraz źródła ich finansowania,

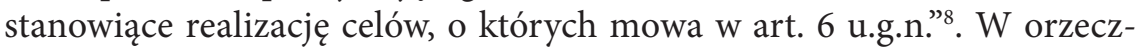
nictwie podkreśla się, że w przedstawionej definicji można wyróżnić dwie składowe cechy pojęcia inwestycji celu publicznego, których wyłącznie kumulatywne stosowanie uprawnia do stwierdzenia, że dana inwestycja ma

4 Konstytucja Rzeczypospolitej Polskiej z dnia 2 kwietnia 1997 r. (Dz.U. z 1997 r. Nr 78, poz. 483 ze zm.) - dalej jako: Konstytucja RP.

5 Ustawa z dnia 27 marca 2003 r. o planowaniu i zagospodarowaniu przestrzennym (tekst jedn. Dz.U. z 2020 r., poz. 293) - dalej jako: u.p.z.p.

6 M. Wolanin, Cel publiczny jako normatywne kryterium oddziaływania na stosunki cywilnoprawne w gospodarce nieruchomościami, cz. I, „Nieruchomości” 2009, nr 9, s. 4.

7 Wyrok WSA w Poznaniu z dnia 28 czerwca 2018 r., IV SA/Po 349/18, Legalis nr 1806398.

8 Art. 2 pkt 5 u.p.z.p. 
charakter inwestycji celu publicznego ${ }^{9}$. „Pierwszą cechą charakteryzującą inwestycję celu publicznego jest jej zakres, tj. określenie czy dane przedsięwzięcie można zaliczyć do działań o znaczeniu lokalnym, ponadlokalnym czy krajowym. Drugą cechą charakterystyczną tego pojęcia jest cel danego zamierzenia, tj. czy stanowi on realizację celów, o których mowa w art. 6 u.g.n." ${ }^{10}$.

Nie nastręcza trudności wykazanie, że realizacja inwestycji drogi publicznej stanowi aktualizację celu określonego w art. 6 u.g.n., bowiem zgodnie z ust. 1 pkt 1 wspomnianego przepisu - „wydzielanie gruntów pod drogi publiczne, drogi rowerowe i drogi wodne, budowa, utrzymywanie oraz wykonywanie robót budowlanych tych dróg, obiektów i urządzeń transportu publicznego, a także łączności publicznej i sygnalizacji”"11 stanowi inwestycję celu publicznego. Zakres inwestycji o stopniu co najmniej lokalnym należy każdorazowo odnosić do konkretnego stanu faktycznego, a więc nie jest możliwe bezrefleksyjne przyjmowanie, że każda inwestycja drogowa zaspokaja interes publiczny, a nie służy wyłącznie interesom prywatnym, czy nawet grupowym ${ }^{12}$.

\section{Lokalizacja inwestycji drogowej a wywłaszczenie nieruchomości}

Na gruncie obowiązujących przepisów można rozpocząć inwestycję drogową na trzy sposoby. Po pierwsze na terenach, gdzie został uchwalony miejscowy plan zagospodarowania przestrzennego, przebieg drogi publicznej może zostać wytyczony przez inwestora na tych nieruchomościach, na których lokalizacja drogi publicznej została przewidziana w planie miejscowym. W drugim przypadku, na obszarach, na których nie obowiązuje plan miejscowy można ulokować drogę publiczną po uzyskaniu ostatecznej decyzji o ustaleniu lokalizacji inwestycji celu publicznego (tryb zwykły) ${ }^{13}$. Począwszy od $2003 \mathrm{r}$. istnieje równocześnie trzecia możliwość - trasę przebiegu inwestycji drogowej można zatwierdzić ostateczną decyzją o zezwoleniu na realizację inwestycji drogowej, tzw. decyzja z.ri.d. Z mocy art. 11 i s.d. ${ }^{14}$ do postępowania o wydanie ostatniej z wymienionych decyzji nie stosuje się przepisów o planowaniu i zagospodarowaniu przestrzennym, dlatego

9 Wyrok NSA z dnia 14 czerwca 2019 r., II OSK 2031/17, Legalis nr 2233707.

10 Wyrok NSA z dnia 17 maja 2017 r., II OSK 2370/15, Legalis nr 1652033.

11 Art. 6 ust. 1 pkt 1 u.g.n.

12 Wyrok WSA w Poznaniu z dnia 28 czerwca 2018 r., IV SA/Po 349/18, Legalis nr 1806398.

13 Art. 50 u.p.z.p.

14 Ustawa z dnia 10 kwietnia 2003 r. o szczególnych zasadach przygotowania i realizacji inwestycji w zakresie dróg publicznych (Dz.U. z 2020 r., poz. 471) - dalej jako: s.d. lub specustawa drogowa. 
realizacja inwestycji drogowej w tym przypadku nie jest uzależniona od treści planów miejscowych (tryb szczególny) ${ }^{15}$.

W trybie zwykłym, te nieruchomości, do których prawa własności nie można nabyć na podstawie umowy cywilnoprawnej ${ }^{16} \mathrm{w}$ oparciu o zasadę swobody umów, gdy np. właściciel nie zgadza się na zaproponowaną przez starostę cenę nabycia nieruchomości, można przejąć po przeprowadzeniu postępowania wywłaszczeniowego i uzyskaniu ostatecznej decyzji wywłaszczeniowej ${ }^{17}$. Przejście prawa własności do wywłaszczonych nieruchomości następuje jako skutek nabycia waloru ostateczności przez konstytutywną decyzję wywłaszczeniową ${ }^{18}$. Przepisy lex specialis, tj. przepisy specustawy drogowej zawierają podobną konstrukcję odjęcia praw do nieruchomości przeznaczonych pod drogi publiczne. Jednakże w wyniku noweli z 2008 r. odstąpiono od wydawania odrębnej decyzji wywłaszczeniowej ${ }^{19}$, a rozstrzygnięcie o wywłaszczeniu stało się integralną częścią decyzji o zezwoleniu na realizację inwestycji drogowej ${ }^{20}$. Tym samym, nie jest wiadome, czy na gruncie specustawy drogowej dochodzi do wywłaszczenia nieruchomości, czy mamy tam wyłącznie do czynienia z przejściem prawa własności i wygaszeniem użytkowania wieczystego oraz ograniczonych praw rzeczowych do nieruchomości oznaczonych w treści decyzji z.r.i.d. Wątpliwości interpretacyjne pojawiły się, ponieważ legalność wywłaszczenia wymaga, aby został wydany odrębny akt administracyjny, który zindywidualizuje podmiot (podmioty, którym przysługują odejmowane prawa do nieruchomości) i skonkretyzuje przedmiot (oznaczona nieruchomość) wywłaszczenia $^{21}$. W toku rozważań nad zagadnieniem stwierdzono, że brak odrębnego postępowania, mającego za przedmiot wywłaszczenie nie-

15 M. Wolanin, Specprocedura realizacji inwestycji drogowej, cz. II, „Nieruchomości” 2010, nr 5, Legalis.

16 Właściwą formą umowy jest akt notarialny w: M. Wojas, Analiza procesu pozyskiwania gruntu pod drogi publiczne na przykładzie odcinka autostrady A1, „Acta Scientorium Polonorum" 2013, nr 3, s. 30.

17 Art. 112 ust. 3 u.g.n.

18 M. Szewczyk, Wywłaszczenie nieruchomości, w: Prawo zagospodarowania przestrzeni, Z. Leoński, M. Szewczyk, M. Kruś (red.), Warszawa 2012, s. 469; zob. art. 121 ust. 1 u.g.n.

19 Likwidacja odrębnego rozstrzygnięcia dotyczącego wywłaszczenia praw do nieruchomości nastąpiła już w drodze nowelizacji specustawy drogowej z 2006 r., jednakże decyzja z.r.i.d. jako jeden akt administracyjny, łączący w sobie liczne rozstrzygnięcia zmierzające do legalnego rozpoczęcia i prowadzenia inwestycji drogowej, pojawiła się dopiero na mocy noweli z 2008 r. w: W. Radziszewska, System prawny dotyczący planowania przestrzennego dróg publicznych w Polsce, „Studia Komitetu Przestrzennego Zagospodarowania Kraju PAN” 2012, nr 142, s. 545.

20 M. Peljan, Ochrona interesu indywidualnego w postępowaniu administracyjnym dotyczacym lokalizacji i budowy dróg publicznych - na podstawie przepisów tzw. specustawy drogowej, Poznań 2014, s. 32.

21 Wyrok WSA w Gdańsku z dnia 17 stycznia 2018 r., II SA/Gd 110/17, Legalis nr 1713041. 
ruchomości, nie wyklucza wywłaszczenia, a konstytucyjna ochrona prawa własności zdaje się stać na przeszkodzie przyjęciu za wiążącą drugiej opcji. Bowiem, po wszczęciu postępowania o wydanie decyzji z.r.i.d., takie rozwiązanie pozbawiałoby posiadaczy praw do nieruchomości ochrony ustanowionej w art. 21 ust. 2 Konstytucji RP, co stawiałoby pod znakiem zapytania konieczność realizacji inwestycji drogowej w trybie specprocedury, zgodnie z celem publicznym i za słusznym odszkodowaniem ${ }^{22} . \mathrm{Na}$ przeszkodzie takiemu rozwiązaniu stoi również dyrektywa spójności i niesprzeczności polskiego systemu prawnego, gdyż wydaje się, że racjonalny ustawodawca nie normowałby odmiennej instytucji prawnej w sposób tożsamy z instytucją wywłaszczenia, w szczególności zrównując jej w skutkach prawnych, tak daleko ingerujących $\mathrm{w}$ prawo własności i jednocześnie nie zapewniając mechanizmów ochronnych dla prawa własności. W efekcie dochodziłoby do nadmiernej ingerencji w prawo własności, która mogłaby zostać zakwalifikowana jako naruszająca istotę prawa własności, a temu na przeszkodzie stoi art. 64 Konstytucji RP. Dlatego słusznym wydaje się przyjęcie, że także na gruncie specustawy drogowej dochodzi do wywłaszczenia, ale będzie to tzw. wywłaszczenie sensu largo ${ }^{23}$, czyli zmodyfikowana wersja wywłaszczenia dokonywanego w świetle przepisów u.g.n. (wywłaszczenie sensu stricto), które mimo braku odrębnego aktu wywłaszczeniowego wciąż wykazuje cechy charakterystyczne dla instytucji wywłaszczenia, w szczególności przez przejęcie ex lege praw majątkowych do nieruchomości, dokonującego się w specyficznych okolicznościach ${ }^{24}$. Podobna wykładnia rozszerzająca stosowanie instytucji wywłaszczenia, ma miejsce w odniesieniu do wywłaszczeń sensu largo, na podstawie ustaw enumeratywnie wskazanych w art. 216 u.g.n. ${ }^{25}$.

Na marginesie można wspomnieć, że także w trybie szczególnym przejście prawa własności na podmiot publicznoprawny jest konsekwencją prawną nabycia przez decyzję z.r.i.d. waloru ostateczności, a nie rozstrzygnięciem organu wydającego rzeczony akt administracyjny ${ }^{26}$.

22 Wyrok TK z dnia 12 grudnia 2017 r., SK 39/15, Legalis nr 1695383.

23 Adam Bodnar, Pismo procesowe RPO z dnia 2 października 2019 r. do sprawy SK 37/19, IV.7003.38.2019.MC, https://www.rpo.gov.pl/ (dostęp: 23.06.2020).

24 Ibidem.

25 K. Muzyczka, Zwrot wywłaszczonej nieruchomości, „Zeszyty Naukowe Państwowej Wyższej Szkoły Zawodowej im. Witelona w Legnicy” 2016, nr 20, s. 72; Wywłaszczeniem sensu largo określa się także dokonywane w ramach umów cywilnoprawnych nabycie nieruchomości na skutek przeprowadzonych rokowań w: S. Pawłowski, Pojęcie, przedmiot i charakter prawny umowy wywłaszczeniowej (ekspropriacyjnej), „Zeszyty Naukowe KUL” 2018, nr 4, s. 160-161.

26 Wyrok WSA w Poznaniu z dnia 17 maja 2017 r., II SA/Po 686/16, Legalis nr 1618419. 


\section{Instytucja zwrotu wywłaszczonej nieruchomości w przepisach ustawy o gospodarce nieruchomościami}

Literatura przedmiotu nadaje instytucji zwrotu wywłaszczonych nieruchomości rangę zasady konstytucyjnej, która oparcie prawne znajduje w art. 21 ust. 2 Konstytucji RP, jako tzw. „oczywista konsekwencja” niewykorzystania nieruchomości na cel wywłaszczenia ${ }^{27}$.

W orzecznictwie wskazuje się, że dla prawidłowości wywłaszczenia, nie wystarczy formalne odebranie praw majątkowych do nieruchomości, ale konieczna jest faktyczna materializacja wywłaszczenia, przez które rozumie się ,przejawy ingerencji władzy publicznej, skutkujące naruszeniem istoty prawa (własności), którym nie towarzyszy formalne odjęcie (odebranie) tego prawa"28. W związku z powyższym, dla legalności wywłaszczenia niezbędne jest nie tylko wskazanie w decyzji wywłaszczeniowej celu publicznego, ale także faktyczna realizacja tego celu przez użycie nieruchomości w sposób zgodny z tym celem ${ }^{29}$. Brak związku między wywłaszczeniem formalnym i faktyczną realizacją celu wywłaszczenia skutkuje aktualizacją przesłanki zawartej w art. 136 ust. 3 u.g.n., zgodnie z treścią, wg której taka nieruchomość jest zbędna na cel wywłaszczenia ${ }^{30}$. Zbędność nieruchomości może przybierać postać prawną lub faktyczną. Z pierwszym rodzajem zbędności mamy do czynienia, jeżeli upadła podstawa dla wydania decyzji wywłaszczeniowej np. decyzja o ustaleniu lokalizacji inwestycji celu publicznego jest nieważna. Druga z nich ma miejsce wtedy, gdy wcale nie podjęto żadnych działań zmierzających do realizacji celu publicznego lub odstąpiono od ich wykonywania ${ }^{31}$.

Praktyka stosowania u.g.n. wymusiła na ustawodawcy ustalenie momentu, kiedy potencjalnie dochodzi do zbędności wywłaszczonej nieruchomości określanej zbędnością domniemaną ${ }^{32}$ W art. 137 u.g.n. przewidziano okres 7 lat na rozpoczęcie prac, mających zrealizować cel wywłaszczenia nieruchomości oraz okres 10 lat na ukończenie realizacji przedmiotowego celu publicznego. Niepodjęcie wyżej wskazanych czynności powoduje bezskuteczny upływ terminów i nieruchomość staje się zbędna na cel określony w treści decyzji wywłaszczającej nieruchomośćs ${ }^{33}$. Ocena aktualizacji

27 P. Tuleja, Konstytucyjne podstawy zwrotu wywłaszczonej nieruchomości, „Gdańskie Studia Prawnicze" 2018, t. XL, s. 338.

28 Wyrok SN z dnia 11 maja 2018 r., II CSK 461/17, Legalis nr 1769143.

29 Wyrok NSA z dnia 15 lipca 2014 r., I OSK 761/13, Legalis nr 1411736.

30 Wyrok NSA z dnia 15 października 2015 r., I OSK 202/14, Legalis nr 1394645.

31 E. Klat-Górska, Zwrot nieruchomości wywłaszczonej według ustawy z dnia 21 sierpnia 1997 r., „Rejent” 1999, nr 2, s. 144.

32 R. Lewicka, Gospodarka nieruchomościami w: Prawo administracyjne materialne. Pojęcia, instytucje, zasady, Z. Duniewska, B. Jaworska-Dębska, M. Stahl (red.), Warszawa 2014, s. 538.

33 Art. 137 ust. 1 pkt 1 i 2 u.g.n. 
zbędności nieruchomości opiera się na wskazaniu, czy doszło do realizacji celu publicznego sprecyzowanego w treści decyzji administracyjnej, a nie na podstawie katalogu $\mathrm{z}$ art. 6 u.g.n. ${ }^{34}$. W związku z tym, w pierwszej kolejności należy ustalić przeznaczenie nieruchomości, a podstawę do tego stanowią przepisy miejscowego planu zagospodarowania przestrzennego, a przede wszystkim skonkretyzowana, co do danej sprawy administracyjnej dokumentacja wywłaszczeniowa ${ }^{35}$. W orzecznictwie podnoszono, że przesłanki te nie mają charakteru łącznego, więc wystarczy materializacja jednej $\mathrm{z}$ nich dla orzeczenia zwrotu ${ }^{36}$. Tym samym, organ nie jest zobowiązany do badania, kiedy doszło do realizacji celu publicznego (np. konkretnej daty wybudowania drogi publicznej), nie musi wskazywać, czy nastąpiło to przed upływem 7 lat, gdyż nie można mówić o zwrocie nieruchomości, gdy cel publiczny został zrealizowany ${ }^{37}$. Podobnie argumentował Naczelny Sąd Administracyjny: „Konsekwencją powyższej wykładni art. 137 ust. 1 pkt 2 u.g.n. $\mathrm{w}$ obecnym brzmieniu jest uznanie, że skoro w chwili złożenia przez byłych właścicieli wniosku o zwrot nieruchomości cel został już na niej zrealizowany, wówczas nie ma podstaw do jej zwrotu, nawet jeśli realizacja celu nastąpiła zdecydowanie później niż przed upływem 10 lat od dnia wywłaszczenia. W przypadku pomyślnej realizacji celu wywłaszczenia przed dniem złożenia wniosku nie jest możliwy zwrot nieruchomości niezależnie od terminu, kiedy ta realizacja nastąpiła" ${ }^{\prime 3}$. W doktrynie wskazuje się, że jest to pogląd mniejszościowy, a przesłanki z art. 137 u.g.n. powinny być stosowane łącznie i wskazane jest każdorazowo (nawet gdy nieruchomość w dacie orzekania jest zagospodarowana zgodnie $\mathrm{z}$ celem wywłaszczenia), precyzyjne ustalanie daty realizacji inwestycji ${ }^{39}$. Powyższe potwierdza orzecznictwo, bowiem „dla oceny zbędności nieruchomości na cel wywłaszczenia jako przesłanki jej zwrotu poprzedniemu właścicielowi kluczowa jest ocena zagospodarowania nieruchomości $w$ terminach określonych $w$ art. 137 ust. 1 u.g.n. Natomiast późniejsze wykorzystanie nieruchomości nie ma znaczenia dla rozstrzygnięcia sprawy zwrotu wywłaszczonej nieruchomości”"

34 P. Charzewski, Przesłanki zwrotu wywłaszczonej nieruchomości - wybrane zagadnienia w: Przestrzeń i nieruchomości jako przedmiot prawa administracyjnego. Publiczne prawo rzeczowe, I. Niżnik-Dobosz (red.), Warszawa 2012, s. 692.

35 Ibidem, s. 693.

36 J. Polanowski, Zmiana paradygmatu przesłanek zwrotu wywłaszczonych nieruchomości w orzecznictwie sq̨dowym, „Administracja: teoria, dydaktyka, praktyka” 2014, nr 4, s. 132.

37 Ibidem, s. 135.

38 Wyrok NSA z dnia 30 lipca 2019 r., I OSK 2287/17, https://sip.lex.pl/orzeczenia-i-pisma-urzedowe/orzeczenia-sadow/i-osk-2287-17-zrealizowanie-celu-wywlaszczenia-wyrok-522827279 (dostęp: 25.06.2020).

39 P. Charzewski, Przesłanki zwrotu..., op. cit., s. 695-696; J. Polanowski, Zmiana paradygmatu..., op. cit., s. 136.

40 Wyrok WSA w Krakowie z dnia 9 września 2016 r., II SA/Kr 629/16, Legalis nr 1542879. 
Podejmując analizę kwestii terminów określonych w art. 137 u.g.n., należy wspomnieć o jednolicie ukształtowanym orzecznictwie sądów administracyjnych, dotykającym problematyki zwrotu nieruchomości wywłaszczonych, na których zrealizowano inwestycję celu publicznego (niekoniecznie zbieżną z celem wywłaszczenia), przed datą wejścia w życie tych norm, ale $\mathrm{z}$ uchybieniem rzeczonym terminom. Zasada lex retro non agit wymaga, by ustaloną datą graniczną dla dopuszczalności zwrotu takich nieruchomości był odpowiednio: dla terminu wskazanego w art. 137 ust. 1 pkt 1 u.g.n. 1 stycznia 1998 r. (tj. data wejścia w życie obecnie obowiązującej u.g.n. i 7-letniego terminu na rozpoczęcie prac zmierzających do realizacji celu publicznego) oraz dla terminu wskazanego $w$ art. 137 ust. 1 pkt 2 u.g.n. - 22 września 2004 r. (tj. data wejścia w życie nowelizacji art. 137 u.g.n., uzależniającej zwrot nieruchomości od 10-letniego terminu na zakończenie realizacji celu publicznego ${ }^{41}$. Zdaniem judykatury, wobec wywłaszczeń nieruchomości dokonanych przed wyżej wskazanymi datami ,terminy określone w art. 137 ust. 1 u.g.n. nie mają zastosowania, ponieważ jako normy materialnoprawne, nie mogą kształtować skutków prawnych stanu faktycznego zaistniałego przed wejściem w życie przepisu określającego te terminy" ${ }^{" 2}$.

Zgodnie z literalnym brzmieniem art. 136 u.g.n. nie jest możliwe przeznaczenie nieruchomości na inny cel niż wskazany w treści decyzji administracyjnej, będącej podstawą przejścia prawa własności do nieruchomości na podmiot publicznoprawny, nawet jeśli ten cel miałby realizować interes publiczny. Od rzeczonej reguły ustawodawca przewidział wyjątek, na mocy którego możliwe jest przeznaczenie wywłaszczonej nieruchomości na inny cel publiczny niż cel wywłaszczenia, o ile organ administracji publicznej zawiadomi o swoim zamiarze poprzedniego właściciela (ewentualnie jego spadkobierców) i dodatkowo udzieli informacji, że istnieje podstawa do zwrotu takiej nieruchomości (informacja dla swojej skuteczności powinna być dokonana jednocześnie z zawiadomieniem o zmianie celu wywłaszczenia ${ }^{43}$. Organem właściwym jest $\mathrm{w}$ tym przypadku organ reprezentujący podmiot publicznoprawny, na rzecz którego przeszło prawo własności nieruchomości, a mianowicie Skarb Państwa lub jednostka samorządu terytorialnego (gmina, powiat, województwo ${ }^{44}$. Organ powinien ustalić obecny adres poprzedniego właściciela (ewentualnie jego spadkobierców), a gdyby było to niemożliwe zamiar przeznaczenia nieruchomości na inny cel publiczny obwieścić w urzędach organów właściwych (urząd gminy, starostwo

41 Wyrok NSA z dnia 22 marca 2013 r., I OSK 1981/11, Legalis nr 760900; wyrok NSA z dnia 8 maja 2013 r., I OSK 2205/11, Legalis nr 762937.

42 Wyrok NSA z dnia 8 maja 2013 r., I OSK 2205/11, Legalis nr 762937.

43 Art. 136 ust. 1 i 2 u.g.n.

44 Wskazane podmioty stają się właścicielami nieruchomości przeznaczonych pod drogi publiczne, zarówno w zwykłym trybie realizacji inwestycji drogowej, na mocy art. 113 ust. 1 u.g.n., jak i w świetle przepisów szczególnych na podstawie art. 12 ust. 4 s.d. 
powiatowe, urząd wojewódzki) oraz na stronie internetowej w Biuletynie Informacji Publicznej, a także w prasie lokalnej o zasięgu minimum powiatowym (rozpowszechnianej na terenie powiatu lokalizacji nieruchomości $)^{45}$. Do zmiany celu wywłaszczenia dochodzi wyłącznie, gdy nie podjęto realizacji celu wskazanego w decyzji wywłaszczeniowej, a wykorzystano nieruchomość na inny jakościowo cel publiczny, a więc taki, który ingeruje $\mathrm{w}$ istotę pierwotnego celu, a nie tylko go nieznacznie modyfikuje np. przez zmianę właściciela ${ }^{46}$.

Uprawnienie poprzednich właścicieli do zwrotu wywłaszczonej nieruchomości jest roszczeniem cywilnoprawnym dochodzonym w postępowaniu administracyjnym ${ }^{47}$ i jest ograniczone czasowo. Termin jego wygaśnięcia wynosi 3 miesiące od dnia doręczenia zawiadomienia lub publicznego ogłoszenia, co oznacza, że po jego upływie żądanie zwrotu jest bezskutecz$n \mathrm{e}^{48}$. W doktrynie wskazuje się, że termin ten ma charakter zawity ${ }^{49}$, oparty na prekluzji, a więc jest terminem, co do którego nie można wydać pozytywnego dla wnioskodawcy postanowienia o przywróceniu terminu do dokonania czynności procesowej ${ }^{50}$.

Ustawa równocześnie przewiduje samodzielne uprawnienie poprzednich właścicieli (ewentualnie ich spadkobierców) do wystąpienia z wnioskiem o zwrot zbędnej na cel wywłaszczenia nieruchomości. Organem właściwym do złożenia wniosku jest starosta, wykonujący zadanie z zakresu administracji rządowej ${ }^{51}$. Uprawnienie i obowiązek zwrotu nieruchomości został, dzięki nowelizacji z 2019 r. ${ }^{52}$ ograniczony czasowo do 20 lat od dnia, w którym decyzja wywłaszczeniowa zyskała walor ostateczności. Po tym terminie niezależnie od woli i wiedzy poprzedniego właściciela, podmiot publicznoprawny będzie mógł zmieniać cel publiczny, który zrealizuje na nieruchomości ${ }^{53}$.

Starosta rozstrzygając o zwrocie nieruchomości wydaje decyzję administracyjną ${ }^{54}$, jednakże pozytywny akt administracyjny, w tym przypadku uzależniony jest od zwrotu świadczenia wzajemnego, tj. odszkodowania lub nieruchomości wzajemnej przez podmiot, który domaga się zwrotu ${ }^{55}$.

45 Art. 136 ust. 2a u.g.n.

46 P. Charzewski, Przesłanki zwrotu..., op. cit., s. 693.

47 M. Maciążek, Zwrot wywłaszczonej nieruchomości a pojęcie nabycia nieruchomości rolnej, „Młody Jurysta” 2018, nr 2, s. 40.

48 Art. 136 ust. 5 u.g.n.

49 R. Lewicka, Gospodarka nieruchomościami..., op. cit., s. 538.

50 P. Charzewski, Przesłanki zwrotu..., op. cit., s. 700.

51 Art. 136 ust. 3 u.g.n.

52 Ustawa $\mathrm{z}$ dnia 4 kwietnia 2019 r. o zmianie ustawy o gospodarce nieruchomościami (Dz.U. z 2019 r., poz. 801).

53 Art. 136 ust. 7 u.g.n.

54 Art. 142 u.g.n.

55 K. Celińska, Wywłaszczenie nieruchomości - aspekty prawne, „Studenckie Zeszyty Naukowe" 2018, nr 37, s. 73. 
Jednocześnie należy pamiętać, że kwota pieniężna odszkodowania powinna zostać zwaloryzowana, przy czym maksymalna wartość waloryzacji jest uzależniona od wartości rynkowej nieruchomości. Organ powinien wziąć pod uwagę wartość rynkową nieruchomości właściwą na dzień zwrotu, a nie na dzień wywłaszczenia lub ustalenia odszkodowania ${ }^{56}$.

\section{Zwrot nieruchomości przeznaczonych pod drogi publiczne}

Bezspornym jest fakt, iż drogi publiczne kwalifikuje się jako tzw. res extra commercium $^{57}$, oznacza to, iż co do zasady, „zwrot nieruchomości, nawet zbędnej [...], nie może nastąpić, jeśli nieruchomość stanowi część drogi publicznej" ${ }^{58}$. Wykonanie na nieruchomości inwestycji drogowej wyklucza zwrot nieruchomości, nawet gdyby przekroczono 10-letni termin realizacji przedsięwzięcia drogowego. „Nieruchomości przeznaczone pod drogi publiczne są rzeczami wyłączonymi z obrotu, choć przeznaczonymi do powszechnego użytku. Wyłączenie nieruchomości z obrotu ma charakter bezwzględny; jest dokonywane tylko ustawą i oznacza niedopuszczalność jakiejkolwiek zmiany podmiotowej w osobie właściciela, niezależnie od sposobu jej dokonania, nikt więc poza Skarbem Państwa lub jednostkami samorządu nie może być właścicielem gruntu przeznaczonego pod drogi publiczne (...). Innymi słowy, skutkiem wyłączenia z obrotu nieruchomości przeznaczonych pod drogi publiczne jest to, że wprawdzie są one przedmiotem prawa własności Państwa lub gminy, lecz może dojść do zmiany właściciela tylko pomiędzy tymi podmiotami i niedopuszczalne jest nabycie tego prawa przez inny podmiot" 59 .

W doktrynie podnosi się, że skoro ustawodawca nie unormował wprost zakazu zwrotu nieruchomości, na której została wybudowana droga publiczna, a która zgodnie z regulacją art. 136 ust. 1 w zw. z art. 137 u.g.n. stała się zbędna na cel wywłaszczenia to taki zwrot będzie dopuszczalny, a jego skutkiem będzie utrata statusu drogi publicznej ${ }^{60}$.

Wojewódzki Sąd Administracyjny w Krakowie wskazał, że inny jest moment wyłączenia dróg publicznych z obrotu w trybie lex generalis $i$ lex specialis. Na podstawie przepisów u.g.n. granicą orzekania o zwrocie nieruchomości jest data wybudowania drogi, co wynika z bezpośredniej korelacji z przepisem art. 2a u.d.p. ${ }^{61}$. W trybie szczególnym jest to z kolei moment

56 Art. 140 ust. 1 i 2 u.g.n.

57 M. Wolanin, Specprocedura realizacji inwestycji drogowej, cz. III, „Nieruchomości" 2010, nr 6, s. 5.

58 Wyrok WSA w Lublinie z dnia 11 kwietnia 2019 r., II SA/Lu 100/18, Legalis nr 1916079.

59 Postanowienie SN z dnia 24 czerwca 2010 r., IV CSK 40/10, Legalis nr 248332.

60 M. Peljan, Ochrona interesu..., op. cit., s. 355.

61 Ustawa z dnia 21 marca 1985 r. o drogach publicznych (tekst jedn. Dz.U. z 2020, poz. 470). 
zawiadomienia o wszczęciu postępowania o wydanie decyzji o zezwoleniu na realizację inwestycji drogowej ${ }^{62}$.

Abstrahując od powyższego, w zasadzie nie budzi wątpliwości dopuszczalność zwrotu nieruchomości drogowych, wywłaszczonych w trybie u.g.n., co wynika zarówno ze wspomnianego art. 21 ust. 2 Konstytucji RP, jak i przepisów rozdziału 6 u.g.n., zawierającego unormowania dotyczące zwrotu. Kwestia zwrotu nieruchomości drogowych stała się problematyczna już po wprowadzeniu regulacji specustawy drogowej, która nie zawiera samodzielnych przepisów normujących zwrot niewykorzystanych pod drogi publiczne nieruchomości, ani też przepisu wprost odsyłającego do bezpośredniego stosowania w tym zakresie u.g.n. ${ }^{63}$ (tj. do zwrotu nieruchomości), wobec których została wydana ostateczna decyzja o zezwoleniu na realizację inwestycji drogowej i do których prawo własności, zgodnie z art. 12 ust. 4 s.d. przeszło na podmiot publicznoprawny ${ }^{64}$.

Judykatura analizując stan de lege lata odnosi się raczej negatywnie do dopuszczalności zwrotu nieruchomości na podstawie przepisów szczególnych, wskazując, że art. 136 u.g.n. ma zastosowanie wyłącznie do wywłaszczeń dokonanych w trybie u.g.n. ${ }^{65}$ i z mocy art. 216 u.g.n. do przepisów ustaw wskazanych w tym artykule (zakaz wykładni rozszerzającej), który w enumeratywnym wyliczeniu nie zawiera specustawy drogowej ${ }^{66}$. Upoważnienia do zwrotu nie tworzy również art. 23 s.d., który odsyła do stosowania przepisów u.g.n. w zakresie nieuregulowanym w rozdziale III s.d., a więc do nabywania nieruchomości pod drogi publiczne, a nie do zasad i trybu ich zwrotu ${ }^{67}$.

Nieruchomość wywłaszczona na podstawie decyzji o zezwoleniu na realizację inwestycji drogowej, nie może być przedmiotem obrotu, a za obrót należy uznać także czynność zwrotu nieruchomości, dokonanie takiej czynności obarczone jest więc wadą nieważności ${ }^{68}$. Ponadto w orzecznictwie wskazuje się, że art. 11 d ust. 9 s.d. „ma charakter bezwzględny i nie przewiduje żadnych wyjątków" ${ }^{69}$, nie prowadząc do kolizji specustawy drogowej i art. 136 ust. 1 u.g.n., zgodnie z którym nie można realizować na wywłaszczonej nieruchomości innego celu publicznego niż określony w decyzji administracyjnej ${ }^{70}$.

62 Wyrok WSA w Krakowie z dnia 19 marca 2014 r., II SA/Kr 1627/13, Legalis nr 1919126.

63 Wyrok NSA z dnia 19 lipca 2017 r., I OSK 2785/15, Legalis nr 1672657.

64 Zob. rozdział III specustawy drogowej.

65 Wyrok NSA z dnia 25 maja 2016 r., I OSK 1975/14, Legalis nr 1485377.

66 Wyrok NSA z dnia 23 września 2010 r., I OSK 1602/09, Legalis nr 340660.

67 Wyrok NSA z dnia 25 maja 2016 r., I OSK 1975/14, Legalis nr 1485377.

68 Wyrok WSA w Łodzi z dnia 21 października 2015 r., II SA/Łd 370/15, Legalis nr 1387758; zob. art. 11 ust. 9 s.d.

69 Wyrok WSA w Krakowie z dnia 19 marca 2014 r., II SA/Kr 1627/13, Legalis nr 1919126.

70 Ibidem. 
Inne stanowisko zdaje się przedstawiać literatura przedmiotu, która podkreśla, że rozdział III specustawy drogowej kompleksowo reguluje kwestie odnoszące się do nabywania nieruchomości drogowych i zagadnienia im towarzyszące, czyli również te dotyczące zwrotu nieruchomości, a mianowicie wszystko co odnosi się do ,przymusowego pozbawienia praw majątkowych"71, o czym mogą świadczyć umieszczone w tym rozdziale przepisy o ustaleniu wysokości odszkodowania i nierozerwalny związek pomiędzy rozdziałami dotyczącymi wywłaszczenia nieruchomości i ich zwrotu w trybie przepisów u.g.n., który powinien być odczytywany per analogiam w stosunku do specustawy drogowej, gdzie te zagadnienia zostały scedowane na regulacje jednego rozdziału ${ }^{72}$.

Odnosząc się do art. 216 u.g.n., orzecznictwo wskazuje, że możliwość zwrotu nieruchomości wywłaszczonych na podstawie decyzji z.r.i.d. będzie uzasadniona, gdyż ze względu na ochronę praw właścicielskich postuluje się szeroką wykładnię art. 136 u.g.n., o czym świadczy wyliczenie wskazane właśnie w art. 216 u.g.n., które nie ma charakteru zawężającego regulację zwrotu, służącą ochronie praw rzeczowych do nieruchomości, a wręcz rozszerza ją na inne akty rangi ustawy ${ }^{73}$.

Możliwość zwrotu wywodzi się także z zasad konstytucyjnych, w szczególności z zasady ochrony praw słusznie nabytych i zasady równości wobec prawa $^{74}$. Wykładnia przepisów specustawy drogowej skutkująca pozbawieniem prawa zwrotu nieruchomości tych podmiotów, dla których odjęcie prawa własności nastąpiło na podstawie ostatecznej decyzji z.r.i.d., prowadziłaby do nieuzasadnionego zróżnicowania ochrony prawnej wobec tożsamych skutków prawnych wynikających z treści decyzji o wywłaszczeniu nieruchomości pod lokalizację drogi publicznej i decyzji o zezwoleniu na realizację inwestycji drogowej ${ }^{75}$. Na uzasadnienie tego stanowiska warto przytoczyć argumenty podniesione w skardze konstytucyjnej, podważającej konstytucyjność art. 216 u.g.n. i art. 23 s.d. w zakresie, w jakim odmawia prawa zwrotu nieruchomości wywłaszczonych w trybie specustawy drogowej, wskazujące na cel wprowadzenia przepisów o zwrocie nieruchomości do polskiego systemu prawnego: „Zasada ta [zasada zwrotu - przyp. Aut.] przede wszystkim ma zapobiec wszelkim nadużyciom, jakie mogą łączyć się z wywłaszczeniem do celów innych niż cele publiczne. [...] nieuwzględnienie w art. 216 u.g.n. specustawy drogowej prowadzi nie tylko do nieusprawiedliwionej dyskryminacji i nierównego traktowania jej adresatów, ale narusza także zasadę proporcjonalności”76. W dalszej części skargi

71 M. Peljan, Ochrona interesu..., op. cit., s. 348.

72 Ibidem.

73 Wyrok NSA z dnia 24 listopada 2017 r., I OSK 969/17, Legalis nr 1801611.

74 M. Peljan, Ochrona interesu..., op. cit., s. 348.

75 Ibidem, s. 349.

76 Skarga konstytucyjna z dnia 4 lutego 2019 r., SK 37/19, https://ipo.trybunal.gov.pl/ ipo/view/sprawa.xhtml?\&pokaz=dokumenty\&sygnatura=SK\%2037/19 (dostęp: 25.06.2020). 
podkreślano, że „uniemożliwienie zwrotu nieruchomości w przypadkach objętych specustawą drogową nie jest racjonalne i społecznie sprawiedliwe, a samo w sobie stanowi podstawę do nadużyć, jak chociażby wykorzystanie procedury pozyskiwania nieruchomości w trybie specustawy drogowej bez późniejszego zamiaru budowy drogi, a jednoczesnym przeznaczeniem gruntu na potrzeby innych inwestycji”"77.

\section{Zakończenie}

Na gruncie obowiązującego stanu prawnego wydaje się, że niemożliwe jest jednoznaczne rozstrzygnięcie o dopuszczalności zwrotu nieruchomości wywłaszczonych decyzją o zezwoleniu na realizację inwestycji drogowej. W przeważającej mierze, orzecznictwo de lege lata nie znajduje podstaw prawnych, aby dopuścić zwrot nieruchomości drogowych, odebranych w trybie specustawy drogowej.

Analizując zagadnienie należy jednak zauważyć, że istnieje wiele przesłanek zawartych $\mathrm{w}$ przepisach rangi konstytucyjnej i ustawowej, które o dopuszczalności zwrotu przesądzają, w szczególności tzw. aspekt negatywny art. 21 ust. 2 Konstytucji RP, stanowiący swoisty środek ochrony praw właścicielskich przed nieuzasadnioną ingerencją władzy publicznej ${ }^{78}$, a także zasada równości, wynikająca $\mathrm{z}$ art. 32 Konstytucji RP i zasada praw słusznie nabytych ${ }^{79}$. Należy opowiedzieć się za przyjęciem, że na podstawie specustawy drogowej mamy do czynienia $\mathrm{z}$ wywłaszczeniem. Co jest konieczne, nawet mimo braku wyraźnego wskazania ustawodawcy, by nie różnicować sytuacji stron postępowania (w szczególności właścicieli i użytkowników wieczystych) w zależności od wszczętego trybu realizacji inwestycji drogowej (zwykłego albo szczególnego), zważywszy, iż wyboru trybu postępowania dokonuje inwestor, który często reprezentuje sporne interesy względem pozostałych stron postępowania.

Niewątpliwie konsekwencje prawne, jakie rodzi odjęcie praw właścicielskich do nieruchomości na podstawie specustawy drogowej są zbieżne ze skutkami wywoływanymi przez zastosowanie instytucji wywłaszczenia. Dyrektywa racjonalności polskiego ustawodawcy wskazuje kierunek wykładni jako rozszerzającej stosowanie art. 136 i n. u.g.n. Żadnego z przepisów prawnych, bowiem nie należy interpretować niejako w oderwaniu od pozostałych norm, występujących w obowiązującym stanie prawnym.

Tym samym, należy wyrazić troskę, iż ustawodawca zdecyduje się na nowelizację art. 23 s.d., dopuszczając literalnie stosowanie przepisów u.g.n., nie tylko do nabywania nieruchomości pod drogi publiczne, ale także do zwrotu

77 Ibidem.

78 K. Siwiec, Zwrot wywłaszczonej nieruchomości przeznaczonej na realizację celu publicznego, „Nieruchomości” 2015, nr 11, s. 16.

79 M. Peljan, Ochrona interesu..., op. cit., s. 348. 
niewykorzystanych dla realizacji celu publicznego nieruchomości, co pozwoli korzystać z dorobku orzeczniczego, na którym opiera się wykładnia przepisów dotyczących zwrotu nieruchomości (tj. rozdział 6 u.g.n.).

Dokonanie zmian ustawodawczych jest wskazane w treści art. 216 u.g.n. przez uzupełnienie katalogu aktów prawnych o ustawę o szczególnych zasadach przygotowania i realizacji inwestycji drogowej (s.d.), by zapewnić spójność regulacji zwrotu nieruchomości przez odesłanie do stosowania rozdziału 6 u.g.n. w razie wszczęcia postępowania na podstawie specustawy drogowej.

Rozwiązaniem stabilizującym obecny stan prawny, byłoby wprowadzenie jednolitej regulacji (osobnej ustawy) służącej przygotowaniu i realizacji inwestycji drogowej, która nie stanowiłaby unormowania przejściowego (czasowego), jak to ma miejsce obecnie, a odniosłaby się równocześnie do kwestii związanych ze zwrotem nieruchomości przeznaczonych pod drogi publiczne. Ważne jest bowiem, zwrócenie uwagi na przesłanki zwrotu nieruchomości z art. 137 u.g.n., w kontekście dróg publicznych. Ustawodawca powinien odnieść się jednoznacznie do tego, czy istnieje możliwość zwrotu nieruchomości, na której wybudowano drogę publiczną, ale uchybiono terminom określonym w tym przepisie (tj. art. 137 u.g.n.), co również jest wątpliwe na podstawie u.g.n., ze względu na przyjęcie wobec dróg publicznych koncepcji tzw. res extra commercium. Wydaje się, że jedynym racjonalnym rozwiązaniem, z racji tak drastycznej ingerencji instytucji wywłaszczenia w prawa właścicielskie, jest wykładnia sprzyjająca ochronie tychże praw, szczególnie, gdy wywłaszczenie dotyka podmiotów prywatnych i należących do nich nieruchomości budynkowych lub lokalowych z przeznaczeniem mieszkalnym. Ewentualny zwrot nie uszczupla bowiem majątku państwowego lub komunalnego, gdyż zawsze towarzyszy mu spełnienie świadczenia wzajemnego w postaci zwrotu odszkodowania.

Reasumując, należy opowiedzieć się zgodnie z poglądami doktryny ${ }^{80} \mathrm{za}$ dopuszczalnością zwrotu także w obecnym stanie prawnym i szeroką wykładnią art. 23 s.d. Zatem, prawidłowo skonstruowaną podstawę prawną będzie w tym przedmiocie stanowić art. 23 s.d. w zw. z art. 136 i 137 u.g.n. ${ }^{81}$.

\section{Bibliografia}

Celińska K., Wywłaszczenie nieruchomości - aspekty prawne, „Studenckie Zeszyty Naukowe" 2018, nr 37.

Charzewski P., Przesłanki zwrotu wywłaszczonej nieruchomości - wybrane zagadnienia w: Przestrzeń i nieruchomości jako przedmiot prawa administracyjnego. Publiczne prawo rzeczowe, I. Niżnik-Dobosz (red.), Warszawa 2012.

80 Zob. M. Peljan, Ochrona interesu..., op. cit., s. 346-364.

81 Zagadnienia poruszone $\mathrm{w}$ artykule były także przedmiotem analizy podjętej w pracy dyplomowej Autorki w: A.A. Kania, Realizacja inwestycji drogowych a planowanie i zagospodarowanie przestrzeni, Kraków 2020. 
Klat-Górska E., Zwrot nieruchomości wywłaszczonej według ustawy z dnia 21 sierpnia 1997 r., „Rejent” 1999, nr 2.

Lewicka R., Gospodarka nieruchomościami w: Prawo administracyjne materialne. Pojęcia, instytucje, zasady, Z. Duniewska, B. Jaworska-Dębska, M. Stahl (red.), Warszawa 2014.

Maciążek M., Zwrot wywłaszczonej nieruchomości a pojęcie nabycia nieruchomości rolnej, „Młody Jurysta” 2018, nr 2.

Muzyczka K., Zwrot wywłaszczonej nieruchomości, „Zeszyty Naukowe Państwowej Wyższej Szkoły Zawodowej im. Witelona w Legnicy” 2016, nr 20.

Pawłowski S., Pojęcie, przedmiot i charakter prawny umowy wywłaszczeniowej (ekspropriacyjnej), „Zeszyty Naukowe KUL” 2018, nr 4.

Peljan M., Ochrona interesu indywidualnego w postępowaniu administracyjnym dotyczacym lokalizacji i budowy dróg publicznych - na podstawie przepisów tzw. specustawy drogowej, Poznań 2014.

Polanowski J., Zmiana paradygmatu przesłanek zwrotu wywłaszczonych nieruchomości w orzecznictwie sąlowym, „Administracja: teoria, dydaktyka, praktyka” 2014, nr 4.

Radziszewska W., System prawny dotyczący planowania przestrzennego dróg publicznych $w$ Polsce, ,Studia Komitetu Przestrzennego Zagospodarowania Kraju PAN" 2012, nr 142.

Siwiec K., Zwrot wywłaszczonej nieruchomości przeznaczonej na realizacje celu publicznego, „Nieruchomości” 2015, nr 11.

Szewczyk M., Wywłaszczenie nieruchomości w: Prawo zagospodarowania przestrzeni, Z. Leoński, M. Szewczyk, M. Kruś (red.), Warszawa 2012.

Wojas M., Analiza procesu pozyskiwania gruntu pod drogi publiczne na przykładzie odcinka autostrady A1, „Acta Scientorium Polonorum” 2013, nr 3.

Tuleja P., Konstytucyjne podstawy zwrotu wywłaszczonej nieruchomości, „Gdańskie Studia Prawnicze" 2018, t. XL.

Wojas M., Analiza procesu pozyskiwania gruntu pod drogi publiczne na przykładzie odcinka autostrady A1, „Acta Scientorium Polonorum” 2013, nr 3.

Wolanin M., Cel publiczny jako normatywne kryterium oddziaływania na stosunki cywilnoprawne w gospodarce nieruchomościami, cz. I, „Nieruchomości” 2009, nr 9.

Wolanin M., Specprocedura realizacji inwestycji drogowej, cz. II, „Nieruchomości” 2010, nr 5, Legalis.

Wolanin M., Specprocedura realizacji inwestycji drogowej, cz. III, „Nieruchomości” 2010, nr 6.

Akty prawne i orzecznictwo:

Konstytucja Rzeczypospolitej Polskiej z dnia 2 kwietnia 1997 r. (Dz.U. z 1997 r. Nr 78, poz. 483 ze zm.).

Ustawa z dnia 4 kwietnia 2019 r. o zmianie ustawy o gospodarce nieruchomościami (Dz.U. z 2019 r., poz. 801).

Ustawa z dnia 10 kwietnia 2003 r. o szczególnych zasadach przygotowania i realizacji inwestycji w zakresie dróg publicznych (Dz.U. z 2020 r., poz. 471). 
Ustawa z dnia 27 marca 2003 r. o planowaniu i zagospodarowaniu przestrzennym (tekst jedn. Dz.U. z 2020 r., poz. 293).

Ustawa z dnia 21sierpnia 1997 r. o gospodarce nieruchomościami (tekst jedn. Dz.U. z 2020 r., poz. 65).

Ustawa z dnia 21 marca 1985 r. o drogach publicznych (tekst jedn. Dz.U. z 2020, poz. 470).

Wyrok SN z dnia 11 maja 2018 r., II CSK 461/17, Legalis nr 1769143.

Postanowienie SN z dnia 24 czerwca 2010 r., IV CSK 40/10, Legalis nr 248332.

Wyrok TK z dnia 12 grudnia 2017 r., SK 39/15, Legalis nr 1695383.

Wyrok TK z dnia 13 grudnia 2012 r., P 12/11, Legalis nr 549572.

Wyrok NSA z dnia 30 lipca 2019 r., I OSK 2287/17, https://sip.lex.pl/orzeczenia-i-pisma-urzedowe/orzeczenia-sadow/i-osk-2287-17-zrealizowanie-celu-wywlaszczenia-wyrok-522827279 (dostęp: 25.06.2020).

Wyrok NSA z dnia 14 czerwca 2019 r., II OSK 2031/17, Legalis nr 2233707.

Wyrok NSA z dnia 24 listopada 2017 r., I OSK 969/17, Legalis nr 1801611.

Wyrok NSA z dnia 19 lipca 2017 r., I OSK 2785/15, Legalis nr 1672657.

Wyrok NSA z dnia 17 maja 2017 r., II OSK 2370/15, Legalis nr 1652033.

Wyrok NSA z dnia 25 maja 2016 r., I OSK 1975/14, Legalis nr 1485377.

Wyrok NSA z dnia 15 października 2015 r., I OSK 202/14, Legalis nr 1394645.

Wyrok NSA z dnia 15 lipca 2014 r., I OSK 761/13, Legalis nr 1411736.

Wyrok NSA z dnia 8 maja 2013 r., I OSK 2205/11, Legalis nr 762937.

Wyrok NSA z dnia 22 marca 2013 r., I OSK 1981/11, Legalis nr 760900.

Wyrok NSA z dnia 23 września 2010 r., I OSK 1602/09, Legalis nr 340660.

Wyrok WSA w Lublinie z dnia 11 kwietnia 2019 r., II SA/Lu 100/18, Legalis nr 1916079.

Wyrok WSA w Poznaniu z dnia 28 czerwca 2018 r., IV SA/Po 349/18, Legalis nr 1806398.

Wyrok WSA w Gdańsku z dnia 17 stycznia 2018 r., II SA/Gd 110/17, Legalis nr 1713041.

Wyrok WSA w Poznaniu z dnia 17 maja 2017 r., II SA/Po 686/16, Legalis nr 1618419.

Wyrok WSA w Krakowie z dnia 9 września 2016 r., II SA/Kr 629/16, Legalis nr 1542879.

Wyrok WSA w Łodzi z dnia 21 października 2015 r., II SA/Łd 370/15, Legalis nr 1387758. Wyrok WSA w Krakowie z dnia 19 marca 2014 r., II SA/Kr 1627/13, Legalis nr 1919126.

Inne

Adam Bodnar, Pismo procesowe RPO z dnia 2 października 2019 r. do sprawy SK 37/19, IV.7003.38.2019.MC, https://www.rpo.gov.pl/ (dostęp: 23.06.2020).

Skarga konstytucyjna z dnia 4 lutego 2019 r., SK 37/19, https://ipo.trybunal.gov. $\mathrm{pl} /$ ipo/view/sprawa.xhtml? \&pokaz=dokumenty\&sygnatura=SK\%2037/19 (dostęp: 25.06.2020). 
Streszczenie

Ingerencja w prawo własności dokonywana w trybie wywłaszczeń stanowi kwestie newralgiczną, szczególnie gdy odjęcie praw rzeczowych następuje na cele budowy lub rozbudowy dróg publicznych. Sytuacja prawna podmiotów, którym odebrano prawa do nieruchomości uległa pogorszeniu po 2006 r., co wiązało się z wprowadzeniem przepisów lex specialis, na gruncie których nie jest jednoznaczna dopuszczalność zwrotu niewykorzystanych na cel wywłaszczenia nieruchomości. Celem niniejszego opracowania jest wskazanie najważniejszych kwestii spornych, które znalazły się w licznych orzeczeniach sądowych i były podejmowane w literaturze przedmiotu. Całość rozważań powinna skłonić do głębszej analizy przedstawionych zagadnień i pozwolić na odniesienie się do sformułowanych wniosków de lege ferenda.

Słowa kluczowe: inwestycja drogowa, wywłaszczenie, zwrot nieruchomości drogowych, droga publiczna

\section{Return of Property Designed for Public Roads under Special Regulations}

Summary

Interference in property rights carried out under expropriations is a sensitive issue, especially when it concerns public road construction or extension. The legal situation of entities whose property rights were withdrawn deteriorated after 2006, which was related to the introduction of lex specialis regulations, which are ambiguous as to the right to allow the return of unused property for the purpose of expropriation. The objective of this study is to identify the most important issues found in numerous court orders and legal literature. All considerations should lead to a deeper analysis of the presented issues and refer to the formulated de lege ferenda conclusions.

Keywords: road investment, expropriation, return of road property, public road 